\title{
SMR
}

\section{Intestinal lactic acid bacteria from Muscovy duck as potential probiotics that alter adhesion factor gene expression}

\author{
Z.L. Xie*, D.P. Bai*, L.N. Xie, W.N. Zhang, X.H. Huang and Y.F. Huang \\ University Key Lab for Integrated Chinese Traditional and Western Veterinary \\ Medicine and Animal Healthcare in Fujian Province, \\ Fujian Agriculture and Forestry University, Fuzhou, China \\ *These authors contributed equally to this study. \\ Corresponding authors: X.H. Huang / Y.F. Huang \\ E-mail: xhhuang138@hotmail.com / zjhyfang138@yahoo.com.cn
}

Genet. Mol. Res. 14 (4): 12262-12275 (2015)

Received February 26, 2015

Accepted May 18, 2015

Published October 9, 2015

DOI http://dx.doi.org/10.4238/2015.October.9.15

\begin{abstract}
The purpose of this study was to assess the suitability of lactic acid bacteria (LABs) isolated from Muscovy duck as a potential probiotic. Isolates were identified by targeted polymerase chain reaction and assessed in vitro for probiotic characteristics such as autoaggregation; surface-charge; hydrophobicity; tolerance to acidic $\mathrm{pH}$, bile salts and protease; and expression of genes involved in Caco-2 cell adhesion. The LAB isolates exhibited strong resistance to high bile concentration and acidic $\mathrm{pH}$, produced lactic acid, and bacteriostatic $(\mathrm{P}$ $<0.05$ ) were identified as bacilli compared with LAB isolates of cocci. Additionally, the LAB isolates showed high sensitivity to penicillin and tetracycline antibiotics, while they were resistant to ofloxacin, Macrodantin, and cotrimoxazole. The level of F-actin mRNA increased in the groups treated with CM3, Salmonella enterica, and CM3 $+S$. enterica $(\mathrm{P}<0.0001, \mathrm{P}<0.05$ and $\mathrm{P}<0.05)$. The level of cell adhesion molecule (CAM) and E-cadherin (E-cad) mRNA expression was significantly lower in the treatment group $(\mathrm{P}<0.05$ for both) than in the
\end{abstract}


control. The F-actin, CAM, and E-cad mRNA levels were significantly lower in the $S$. enterica and CM3 $+S$. enterica groups $(\mathrm{P}<0.01)$ than in the CM3 group. Among these, RNA levels were higher in the CM3 + $S$. enterica than $S$. enterica group. These results indicate that the natural duck gut microflora is an excellent source for probiotic bacteria and can facilitate the establishment of criteria to select probiotic strains for the prevention of diarrhea.

Key words: Muscovy duck; Lactic acid bacteria; Probiotic; Adhesion factor gene expression

\section{INTRODUCTION}

Gastrointestinal illness, such as diarrhea, in young animals has a significant impact on animal husbandry. The use of probiotics sourced from indigenous microbiota could prevent pathogenic colonization in the digestive tract and act as a barrier against toxic substances and pathogens (Long and Swenson, 1977; Nemcova, 1997; Zoetendal et al., 2006; Neal-McKinney et al., 2012). Previous studies show that lactic acid bacteria (LABs) and related microorganisms initially colonize the intestinal tract and subsequently, prevent colonization of intestinal pathogens (Long and Swenson, 1977). Thus, the appropriate use of probiotics could prevent illnesses and increase productivity of reared animals (Fuller, 1989).

Probiotics are administered to produce a beneficial physiological effect (Mountzouris et al., 2007), often as an adjuvant to provide protection to newborns (Brink et al., 2005; Saxelin, 2008; Tsirtsikos et al., 2012). Lactobacilli are an important species of probiotics (Fuller, 1989; Otero et al., 2006; Martin et al., 2007; Karunasena et al., 2013), known to provide resistance against pathogens such as Escherichia coli (Shu and Gill, 2002) and Salmonella (Calderon et al., 2007). In vivo studies have shown that LABs colonize the intestinal tract of mice and provide protection against Salmonella (Calderon et al., 2007).

Previous studies demonstrated that probiotic strains prevented colonization by pathogens mainly by adhesion to the intestinal tract or production of bactericidal substances (Ocana and Nader-Macias, 2002; Otero et al., 2006). The purpose of this study was to isolate LABs from young Muscovy ducks and determine resistance to intestinal tract conditions (acidic $\mathrm{pH}$, bile etc.). Moreover, we determined if the LAB isolates could function as probiotics when administered to other Muscovy ducks, in terms of bacteriostatic activity and adhesion factor gene expression.

\section{MATERIAL AND METHODS}

\section{Animals and collection of samples}

We obtained 30 healthy Muscovy ducks ( $<4$ weeks old) from Muscovy duck farms in Fujian Province, China. These ducks had not received antibiotics in the 2 or 3 weeks and had been determined as clinically healthy (based on body weight, food intake, and absence of diarrheal symptoms). Samples of intestinal contents were collected and stored in de Man, Rogosa and Sharpe (MRS) medium containing $1.5 \%$ agar, $\mathrm{pH} 6.2$, at $4^{\circ} \mathrm{C}$. Before use, the sample solutions were resuspended $\left(10^{-1}\right.$ dilution $)$ in peptone water, followed by serial dilutions. Ali- 
quots of each dilution were inoculated in MRS broth ( $1 \%$ meat extract, $1 \%$ casein, $0.4 \%$ yeast extract, $2 \%$ glucose, $0.108 \%$ Tween- 80 ), and plated on MacConkey agar (Britania, Buenos Aires, Argentina), and MRS agar, in order to quantify enterobacteria and LABs, respectively.

\section{Presumptive identification of the microorganisms}

We performed a Gram stain to determine morphology and the catalase (Sigma, Shanghai, China) reaction to detect gas production from glucose in PY medium, containing $500 \mu \mathrm{L}$ Tween-80, $0.5 \%$ agar, and $1.6 \%$ bromcresol purple. Gas production from gluconate was detected using gluconate medium and tubes were sealed with a layer of Vaseline-paraffin (1:1). LABs were inoculated into both, PY and gluconate media, and incubated for $48 \mathrm{~h}$ at $37^{\circ} \mathrm{C}$.

The degradation of $\mathrm{H}_{2} \mathrm{O}_{2}$ was determined to identify LAB isolates as previously described (Otero et al., 2004). The isolated LABs were inoculated on MRS agar (Sigma Chemical Co, St. Louis, MO, USA) plates and incubated for $24 \mathrm{~h}$ at $37^{\circ} \mathrm{C}$. Extent of effervescence produced by the isolate in the plate using $15 \% \mathrm{H}_{2} \mathrm{O}_{2}$ was scored as negative (-) weakly positive $(+)$, moderately positive $(++)$, or strongly positive $(+++)$.

\section{Genetic identification of the isolated strain}

The isolated $\mathrm{LAB}$ was further identified by $16 \mathrm{~S}$ rRNA gene sequencing. Colonies on MRS agar were picked up, and the DNA, which was extracted by the QIAmp DNA Mni Kit (QIAGEN, Guangzhou, China) as per the manufacturer instructions, was amplified by polymerase chain reaction (PCR) using the GoTaq ${ }^{\circledR}$ DNA polymerase kit (containing GoTaq ${ }^{\circledR}$ DNA Polymerase, 5X Green GoTaq ${ }^{\circledR}$ Reaction Buffer, and 5X Colorless GoTaq ${ }^{\circledR}$ Reaction Buffer; Promega, Xiamen, USA), $1 \mu \mathrm{M}$ forward (5'-AGAGTTTGATCCTGGCTCAG-3') and reverse (5'-TAGGGTTACCT- TGTTACGACTT-3') primers, and Milli-Q (Milli-Q Gradient, Shanghai, China) water. The final reaction volume was $25 \mu \mathrm{L}$. PCR was performed using a CFX96TM-C1000 thermal cycler (BioRad, USA) under the following conditions: 5 min at $95^{\circ} \mathrm{C}$ for initial denaturation; 35 cycles consisting of $30 \mathrm{~s}$ at $95^{\circ} \mathrm{C}, 30 \mathrm{~s}$ at $55^{\circ} \mathrm{C}$, and $90 \mathrm{~s}$ at $72^{\circ} \mathrm{C}$; and final extension for $10 \mathrm{~min}$ at $72^{\circ} \mathrm{C}$. PCR products were electrophoresed on $1.0 \%$ agarose gels, purified, and sequenced via the DNA sequencing service provided by Sangon Biotechnology, Shanghai, China. Our 16S rRNA sequences were identified by comparison with those deposited in the GenBank database by using the BLAST search.

\section{Organic acid quantification}

Supernatant fractions $(1 \mathrm{~mL})$ from the 3rd subculture in MRS broth incubated for 16 $\mathrm{h}$ at $37^{\circ} \mathrm{C}$ were analyzed for lactic acid production by high-pressure liquid chromatography. A column (BioRad HPX-87H $300 \times 7.8 \mathrm{~mm}$ ) at $41^{\circ} \mathrm{C}$ temperature within the KS System chromatographer (Knauer, Germany), $5 \mathrm{mM} \mathrm{H}_{2} \mathrm{SO}_{4}, \mathrm{pH}$ 2, as eluent, flow rate of $0.5 \mathrm{~mL} / \mathrm{min}$, and a Knauer K-2301 (Knauer, German) refractive index detector were used for organic acid detection.

\section{Inhibitory activity against different pathogens}

The inhibitory substance in the supernatant fluid of the isolates was evaluated by the 
plate diffusion technique (Nemcova, 1997). Briefly, pathogenic strains were inoculated at a concentration of $10^{5}$ colony-forming units $(\mathrm{CFU}) / \mathrm{mL}$ on $1.5 \% \mathrm{MRS}$ agar plates. Supernatant fractions $(1 \mathrm{~mL})$ from the 3rd subculture in MRS broth were placed into 4-mm holes punched into the agar of the MRS plates; subsequently, the plates were incubated for $24 \mathrm{~h}$ at $37^{\circ} \mathrm{C}$. An inhibition zone of $\geq 6 \mathrm{~mm}$ was considered as a positive result. Supernatants testing positive were treated with catalase $(1000 \mathrm{U} / \mathrm{mL})$ to determine the nature of the hydrogen peroxide and organic acids produced. Pathogens including E. coli, Staphylococcus aureus, Salmonella spp, and Bacillus cereus isolated from clinical samples of poultry and laboratory stock cultures were used to evaluate the inhibitory activity of the isolated LABs.

\section{Tolerance to acidic pH}

Bacteria were cultured in MRS broth at $37^{\circ} \mathrm{C}$ overnight, followed by incubation for another $24 \mathrm{~h}$ in fresh MRS broth. The MRS broth was collected and centrifuged at $3000 \mathrm{~g}$ for $15 \mathrm{~min}$ at $4^{\circ} \mathrm{C}$, and pellets were washed twice and re-suspended in sterile phosphate-buffered saline (PBS), pH 7.2. Each strain was diluted 1:10 in PBS at pH 2, 3, 4, 5, and 6. Subsequently, $\mathrm{LAB}$ isolates were transferred into MRS media and broth, and incubated aerobically at $37^{\circ} \mathrm{C}$ for $24 \mathrm{~h}$. Count of surviving cells was determined by plating on MRS agar.

\section{Tolerance to bile salts}

MRS media with bile (Sigma, Shanghai, China) at concentrations of 2, 4, 6, 8 and 10 $\mathrm{g} / \mathrm{L}$ were prepared. Samples of the 3 rd subcultures of LABs $(2 \mu \mathrm{L}$ each, corresponding to $6 \mathrm{x}$ $10^{8} \mathrm{CFU} / \mathrm{mL}, 5$ repetitions for each isolate) were spotted onto MRS-bile medium and incubated aerobically for $24 \mathrm{~h}$ at $37^{\circ} \mathrm{C}$.

\section{Tolerance to protease}

$\mathrm{LAB}$ isolates were cultured in MRS broth at $37^{\circ} \mathrm{C}$ for $24 \mathrm{~h}$ and subcultured into fresh MRS broth and incubated for another $24 \mathrm{~h}$. MRS media with trypsin (Sigma, Shanghai, China) at concentrations of $8,10,12,14$, and $16 \mathrm{~g} / \mathrm{L}$ were prepared. Samples of the 3 rd subcultures of LABs $\left(2 \mu \mathrm{L}\right.$ each, corresponding to $\left.6 \times 10^{8} \mathrm{CFU} / \mathrm{mL}\right)$ were spotted onto MRS-trypsin medium, incubated for $24 \mathrm{~h}$ at $37^{\circ} \mathrm{C}$, and detected at $\mathrm{OD}_{600}$.

Tolerance to pepsin (Sigma, Shanghai, China) was determined as per the procedure used for trypsin tolerance. MRS medium containing 37\% hydrochloric acid (wt/v) (Guoyao, Shanghai, China), $\mathrm{pH} 3.0$, was prepared and $5 \mathrm{mg} / \mathrm{mL}$ pepsin (NF $3000 \mathrm{U} / \mathrm{mg}$ ) was added to simulate gastric juice. MRS medium without pepsin, $\mathrm{pH} 6.25$, was used as control. Samples of the 3rd subculture of LABs ( $2 \mu \mathrm{L}$ each, corresponding to $\left.6 \times 10^{8} \mathrm{CFU} / \mathrm{mL}\right)$ were spotted onto MRS-pepsin medium and incubated for $24 \mathrm{~h}$ at $37^{\circ} \mathrm{C}$ and detected at $\mathrm{OD}_{600}$.

\section{Antibiotic sensitivity}

LABs were activated by incubating in MRS broth at $37^{\circ} \mathrm{C}$ overnight, followed by incubation for another $24 \mathrm{~h}$ in fresh MRS. Bacterial concentration was adjusted to $3 \times 10^{8} \mathrm{CFU} /$ $\mathrm{mL}$ and the suspension was added to sterile LB molten medium $\left(45^{\circ} \mathrm{C}\right)$ in a proportion of 1:25 (v:v). Antibiotic susceptibility discs was gently fixed on the agar surface and plates were incubated for $24 \mathrm{~h}$ at $37^{\circ} \mathrm{C}$ to determine inhibition zones. 


\section{Characterization of adhesion and reverse transcriptase (RT)-PCR}

Bacterial cell surface hydrophobicity and adherence to epithelial and Caco-2 cells were investigated to characterize the adhesion ability of LABs. Cell surface hydrophobicity was tested as previously described (Handley et al., 1987; Otero et al., 2004). Samples of the $3 \mathrm{rd}$ subcultures and saline-washed lactobacilli $\left(\mathrm{OD}_{600}=0.6\right)$ were mixed with the same volume of n-hexadecane (Sigma, Shanghai, China). After a separation time of $60 \mathrm{~min}$, the decrease in OD of the aqueous phase was used as a measure of cell surface hydrophobicity. In vitro, adherence to epithelial cells was determined as previously described (Tuomola and Salminen, 1998; Matisjaic, et al., 2003). The Caco-2 cell line was purchased from the Institute of Biochemistry and Cell Biology, Shanghai. Caco-2 cell was cultured and cell concentration was adjusted to $4 \times 10^{5} \mathrm{CFU} / \mathrm{mL}$, while LAB cell concentration was adjusted to $1 \times 10^{8} \mathrm{CFU} / \mathrm{mL}$. The two suspensions were mixed in a ratio of $1: 4(\mathrm{v}: \mathrm{v})$ and incubated for $30 \mathrm{~min}$ at $37^{\circ} \mathrm{C}$ in a shaking water bath ( $25 \mathrm{rev} / \mathrm{min})$. Adhesion was observed microscopically and scored positive if at least 10 adhered bacteria could be observed per Caco- 2 cell. A confirmatory adhesion assay was performed with Caco- 2 cells using phase-contrast microscopy.

LAB cells were collected by centrifuged at $3000 \mathrm{rpm} / \mathrm{min}$ and immediately subjected to RNA extraction using Trizol (TaKaRa, Dalian, China) following manufacturer instructions. The mRNA expression level was determined as previously described (Bionaz and Loor, 2011). Quantitative PCR (qPCR) was performed using a Bio-Rad MyiQ ${ }^{\mathrm{TM}}$ Detection System (Applied Biosystems, USA) as previously described (Xie et al., 2015). The nucleotide sequences of adhesion factor were used for primer design and search in the European Bioinformatics Institute database (http://www.ebi.ac.uk/). The primers used were as follows: cell adhesion molecule (CAM; F: 5'-ctgatgatgacgtgagcagc-3'; R: 5'-gactcccatgtgagtgtcca-3'), E-cadherin (E-cad; F: 5'-cgtagcagtgacgaatgtgg-3'; R: 5'-ctgggcagtgtaggatgtga-3') and F-actin (F: 5'-cgtggtagaagtgcaggaga-3'; R: 5'-ccgatgttggctatgtgtgg-3'). The reaction conditions were as follows: 5 min at $95^{\circ} \mathrm{C}, 40$ cycles of $40 \mathrm{~s}$ at $94^{\circ} \mathrm{C}$ and $40 \mathrm{~s}$ at $60^{\circ} \mathrm{C}$, followed by a final extension at $72^{\circ} \mathrm{C}$ for $10 \mathrm{~min}$. The final data were recorded, and the comparative threshold cycle $(\mathrm{Ct})$ method was used to calculate the amount of target mRNA normalized to GADPH and relative to an internal control by $2^{-\Delta \Delta C t}$ method (Xie, et al., 2015).

\section{Statistical analysis}

All analyses were conducted in duplicate in 2 independent fermentation surveys. Data obtained were subjected to ANOVA and means were separated by the Tukey multiple comparison tests using SPSS 16.0. The mean difference was considered significant at the 0.05 level.

\section{RESULTS}

\section{Presumptive identification and characterization of microorganisms}

The enterobacteria isolated from Muscovy ducks (between 1- to 4-week-old) showed no statistically significant differences in the numbers of LABs. A total of 58 isolates were identified as LABs: $78 \%$ of the bacilli and cocci were isolated from Muscovy ducks, with a majority of cocci (26 isolates) and bacilli (29 isolates) isolated from ducks on farms. We identified 6 different categories and designated them as CM1, CM2, CM3, CM4, CM5, and CM6. The 
isolates in CM2, CM4, and CM5 were spherical or elliptical, in pairs or short chains, while those in CM1, CM3, and CM6 were short or long rods, as shown in Figure 1A. Sequencing of the 16S rRNA gene of CM1, CM2, CM3, CM4, CM5, and CM6 showed similarity to Lactobacillus rhamnosus (99\%), Lactococcus lactis subsp lactis (99\%), Lactobacillus salivarius (99\%), Streptococcus lactis (99\%), Enterococcus columbae (99\%), and Lactobacillus murinus $(99 \%)$ in GenBank sequences and rooted the phylogenetic tree (Figure1B and C).

Table 1 summarizes the individual characteristics of the isolates by hydrophobicity and autoaggregation. The surface characteristics of the LAB isolates were evaluated and a higher degree of hydrophobicity was observed in several isolates in the Lactobacillus group. The autoaggregation ability increased with time (from 0 to $12 \mathrm{~h}$ ). Overall, the LAB isolates expressed $>90 \%$ hydrophobicity and the surface charge of the LAB isolates was higher in the group treated with ethyl acetate than those treated with chloroform.
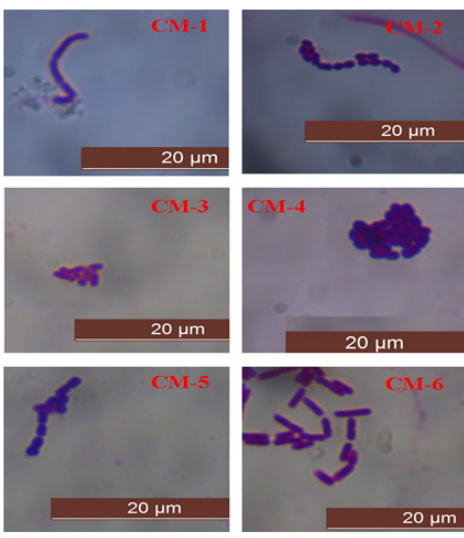

A

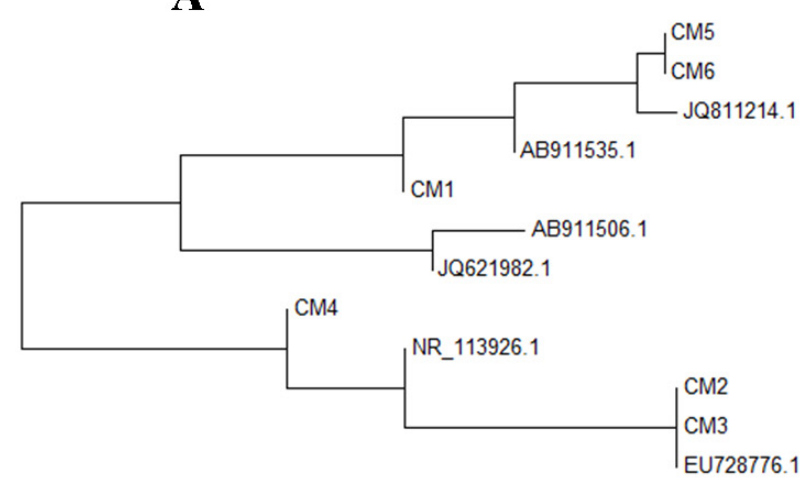

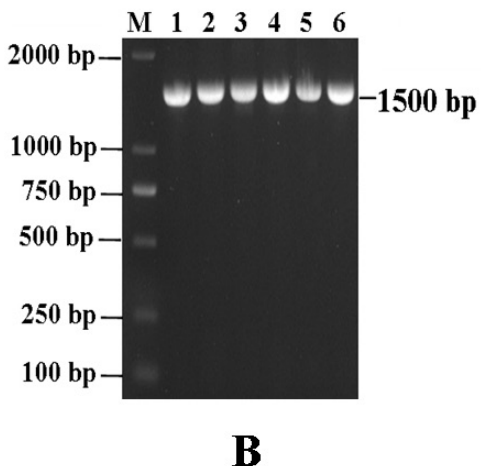

B C

Figure 1. Bacteria isolated and identified from intestinal contents of Muscovy ducks. A. Gram staining of Lactobacillus screened from Muscovy duck intestine. B. Amplified Lactobacillus 16S rRNA from Muscovy duck intestine via reverse transcriptase (RT)-polymerase chain reaction (PCR). RT-PCR product size was $1500 \mathrm{bp}$ and amplicons were by electrophoresed on 2\% agarose gel. Lane M: DNA marker DL-2000; Lanes 1-6: products of first-screen Lactobacillus 16S rRNA from Muscovy duck intestine, designated CM1, CM2, CM3, CM4, CM5, and CM6. C. Rooted phylogenetic tree of isolates strains, based on a 16S rRNA gene sequence. 
Table 1. Characteristics of hydrophobicity, autoaggregation, and surface charge with LAB isolates.

\begin{tabular}{|c|c|c|c|c|}
\hline \multirow[t]{2}{*}{ Strains } & \multirow{2}{*}{$\frac{\text { Hydrophobicity }(\%)}{\text { Hexadecane }}$} & \multirow[t]{2}{*}{ Autoaggregation (\%) } & \multicolumn{2}{|c|}{ Surface charge $(\%)$} \\
\hline & & & Ethyl acetate & Chloroform \\
\hline CM1 (Lactobacillus rhamnosus) & $96.79 \pm 3.75$ & $61.36 \pm 1.76$ & $97.94 \pm 2.78$ & $84.77 \pm 1.75$ \\
\hline CM2 (Lactococcus lactis subsp Lactis) & $98.66 \pm 1.75$ & $72.55 \pm 3.10$ & $95.72 \pm 6.55$ & $93.33 \pm 0.35$ \\
\hline CM3 (Lactobacillus salivarius) & $99.79 \pm 2.66$ & $90.16 \pm 2.33$ & $99.72 \pm 1.58$ & $86.53 \pm 7.33$ \\
\hline CM4 (Streptococcus lactis) & $99.72 \pm 3.68$ & $52.59 \pm 2.29$ & $96.12 \pm 1.43$ & $92.52 \pm 2.98$ \\
\hline CM5 (Enterococcus columbae) & $99.23 \pm 1.33$ & $57.89 \pm 1.84$ & $95.67 \pm 2.75$ & $85.36 \pm 1.02$ \\
\hline CM6 (Lactobacillus murinus) & $98.77 \pm 1.46$ & $49.72 \pm 3.51$ & $96.18 \pm 2.45$ & $85.52 \pm 2.32$ \\
\hline
\end{tabular}

Data are reported as means \pm SEM.

\section{Bacteriostatic activity of isolated strains}

LAB isolates sharing beneficial properties (hydrophobicity and autoaggregation) were selected and identified by genetic methods (Table 1). The results show that $33 \%$ bacilli were moderate producers $(++)$ of hydrogen peroxide (Table 2 ). The strains that produced inhibitory substances were identified as probiotic and capable of protecting the intestinal steady state condition, on account of lactic acid production (Table 2). As per Table 2, the LAB isolates in CM2, CM4, and CM5 were cocci and produced lower amounts of lactic acid than those in CM1, CM3, and CM6 categories. As per Table 2, LAB isolates in CM3 showed significant bacteriostatic activity, especially inhibiting Salmonella $(\mathrm{P}<0.05)$ and B. cereus $(\mathrm{P}<0.05)$. The inhibitory zone diameter for Salmonella and B. cereus was significantly larger than that for E. coli and S. aureus, respectively (Table 3).

Table 2. Inhibitory substances produced of LAB isolated from Muscovy ducks.

\begin{tabular}{|c|c|c|c|c|}
\hline Strains & Lactic acid $(\mathrm{g} / \mathrm{L})^{\mathrm{a}}$ & $\mathrm{pH}$ supernatant $\mathrm{t}^{\mathrm{b}}$ & $\mathrm{H}_{2} \mathrm{O}_{2}$ production $^{\mathrm{c}}$ & Gas production \\
\hline$\overline{\text { CM1 (Lactobacillus rhamnosus) }}$ & 7.52 & $4.75 \pm 0.19$ & - & - \\
\hline CM2 (Lactococcus lactis subsp Lactis) & 9.73 & $3.97 \pm 0.22$ & - & - \\
\hline CM3 (Lactobacillus salivarius) & 15.56 & $5.11 \pm 0.19$ & - & - \\
\hline CM4 (Streptococcus lactis) & 8.96 & $4.40 \pm 0.24$ & - & - \\
\hline CM5 (Enterococcus columbae) & 6.01 & $4.37 \pm 0.23$ & - & - \\
\hline CM6 (Lactobacillus murinus) & 11.56 & $4.28 \pm 0.24$ & ++ & - \\
\hline
\end{tabular}

Data are partially reported as means \pm SEM. ${ }^{a}$ Lactic acid production was determined by HPLC in a 16-h culture in MRS broth. ${ }^{b} \mathrm{pH}$ of the supernatant was determined using a pHmeter. ${ }^{\mathrm{c}}$ The degradation of $\mathrm{H}_{2} \mathrm{O}_{2}$ was determined to identify LAB isolates as previously described (Otero et al., 2004). A scored was assigned as negative (-), weakly positive $(+)$, moderately positive $(++)$, or strongly positive $(+++)$.

Table 3. Bacteriostasis activity comparison of Lactobacillus.

\begin{tabular}{lcccccc}
\hline Indicator bacteria strains & \multicolumn{5}{c}{ Inhibitory zone diameter (mm) } \\
\cline { 2 - 6 } & CM1 & CM2 & CM3 & CM4 & CM5 \\
\hline Escherichia coli & $13.55 \pm 1.10^{\mathrm{ab}}$ & $15.06 \pm 0.31^{\mathrm{ab}}$ & $15.13 \pm 2.15^{\mathrm{ab}}$ & $14.60 \pm 1.89^{\mathrm{ab}}$ & $12.18 \pm 1.06^{\mathrm{ab}}$ & $13.40 \pm 2.35^{\mathrm{ab}}$ \\
Salmonella & $18.95 \pm 2.57^{\mathrm{ab}}$ & $10.85 \pm 1.64^{\mathrm{ab}}$ & $20.41 \pm 1.22^{\mathrm{ab} *}$ & $13.40 \pm 3.31^{\mathrm{ab}}$ & $15.32 \pm 2.04^{\mathrm{ab}}$ & $16.45 \pm 1.12^{\mathrm{ab}}$ \\
Bacillus cereus & $20.27 \pm 2.34^{\mathrm{ab}}$ & $13.00 \pm 2.70^{\mathrm{ab}}$ & $22.38 \pm 2.19^{\mathrm{ab} *}$ & $19.80 \pm 0.97^{\mathrm{ab}}$ & $17.21 \pm 2.18^{\mathrm{ab}}$ & $18.49 \pm 1.41^{\mathrm{ab}}$ \\
Staphylococcus aureus & $10.93 \pm 1.38^{\mathrm{ab}}$ & $12.01 \pm 2.22^{\mathrm{ab}}$ & $13.19 \pm 1.69^{\mathrm{ab}}$ & $14.17 \pm 0.79^{\mathrm{ab}}$ & $14.42 \pm 1.58^{\mathrm{ab}}$ & $17.26 \pm 1.27 \mathrm{ab}^{*}$ \\
\hline
\end{tabular}

Values of same row with same letter superscripts mean $\mathrm{P}>0.05$ and with different small or capital letter superscripts mean $\mathrm{P}<0.05$. *Muscovy duck intestinal isolated lactobacillus has significantly bacteriostatic effect on indictor strains $(\mathrm{P}<0.05)$. 


\section{Tolerance characteristic of isolated strains}

Bacteriocin produced by 6 of the LAB isolates was inactivated by acidic $\mathrm{pH}$, bile salts, and protease, as shown in Figure 2. Most of the LAB isolates were able to grow in media at $\mathrm{pH}$ in the range of 3 to 6 , but the survival rate of LAB isolates dropped significantly when the $\mathrm{pH}$ dropped below 3 . The survival rate of bacilli was significantly higher than that of cocci at $\mathrm{pH}$ 2 and significantly increased with increasing $\mathrm{pH}(\mathrm{P}<0.05)$ (Figure 2A). This result indicated that the bacillary isolates have strong acid resistance.

The $\mathrm{LAB}$ isolates were sensitive to different concentrations of bile and showed growth in media containing 2, 4, 6, and $8 \mathrm{~g} / \mathrm{L}$ bile salts (Figure 2B-1). Additionally, LAB isolates identified as bacilli were able to resist $10 \mathrm{~g} / \mathrm{L}$ bile concentration and most of the $\mathrm{LAB}$ isolates grew at the lowest concentration $(2 \mathrm{~g} / \mathrm{L}$ ) (Figure 2B-1). However, of the 6 categories of LAB isolates, only the survival rate of CM3 was more than $25 \%$ at the highest concentration (10 g/L) (Figure 2B-2). The survival rate of bacilli was significantly higher than that of cocci at 4,6 , and $8 \mathrm{~g} / \mathrm{L}$ bile salts concentrations $(\mathrm{P}<0.05)$. However, the survival rate of $\mathrm{LAB}$ isolates decreased with an increase in bile concentrations, wherein all concentrations after $2 \mathrm{~g} / \mathrm{L}$ bile salts showed a significant decline in survival of LAB isolates $(\mathrm{P}<0.05)$. Additionally, the survival rate of cocci was lower than that of bacilli (Figure 2B1). Growth inhibition by protease was dependent on strong release of acids into the media by inhibitory strains. The survival rate of bacilli was significantly higher in the media at $\mathrm{pH}$ 3 with $5 \mathrm{mg} / \mathrm{mL}$ pepsin, than that of cocci $(\mathrm{P}<0.05)$ (Figure $2 \mathrm{C})$. With trypsin treatment, the activity of LABs was higher than that of cocci. In addition, resistance to trypsin showed a negative correlation with trypsin concentration and significantly decreased for all LABs $(\mathrm{P}<0.05)$ (Figure 2D).

According to Table 4, 6 LAB isolates were sensitive to penicillin and tetracycline antibiotics, while they were resistant to ofloxacin, Macrodantin, and cotrimoxazole. Among these, CM1, CM2, CM4, and CM5 showed a high level of sensitivity to ampicillin and doxycycline, whereas CM6 was sensitive to ampicillin alone.

\section{Characterization of adhesion and involvement of gene expression}

Bacterial cell adherence to Caco-2 cell was determined by phase-contrast microscopy and the results show that LAB isolates adhered to Caco-2 cell (Figure 3A, B, C, D, $\mathrm{E}$, and F). Among these, CM5, CM4, and CM2 strains, identified as cocci, showed adhered bacterial cell numbers of $32.9 \pm 4.80,31.3 \pm 3.50$, and $30.8 \pm 2.30 \mathrm{CFU} / \mathrm{Caco}-2$ cell, respectively. These values are significantly higher than those obtained for LABs $(\mathrm{P}<0.05)$ identified as bacilli (Figure 3G).

The quantities of adhesion factor mRNAs are summarized in Figure 4. Compared with the control group, F-actin mRNA increased in CM3 $(\mathrm{P}<0.0001)$, Salmonella enterica $(\mathrm{P}<0.05)$, and $\mathrm{CM} 3+S$. enterica groups $(\mathrm{P}<0.05)$. CAM and E-cadherin mRNA significantly decreased in the $S$. enterica $(\mathrm{P}<0.05)$ and $\mathrm{CM} 3+$ S. enterica groups $(\mathrm{P}<0.05)$ compared with the control. Interestingly, all the adhesion factor mRNA levels significantly decreased in the $S$. enterica $(\mathrm{P}<0.01)$ and $\mathrm{CM} 3+S$. enterica groups $(\mathrm{P}<0.01)$ compared with the levels in the CM3 group. In particular, the CAM mRNA level was higher in the $\mathrm{CM} 3+S$. enterica group than in the S. enterica group. 


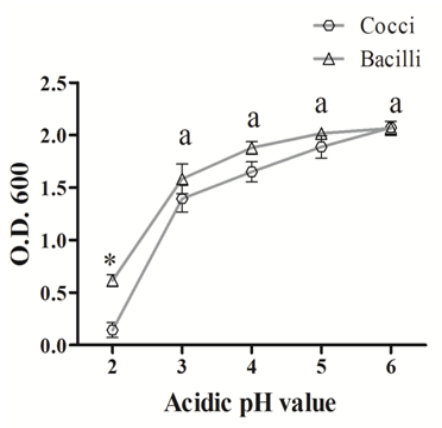

A

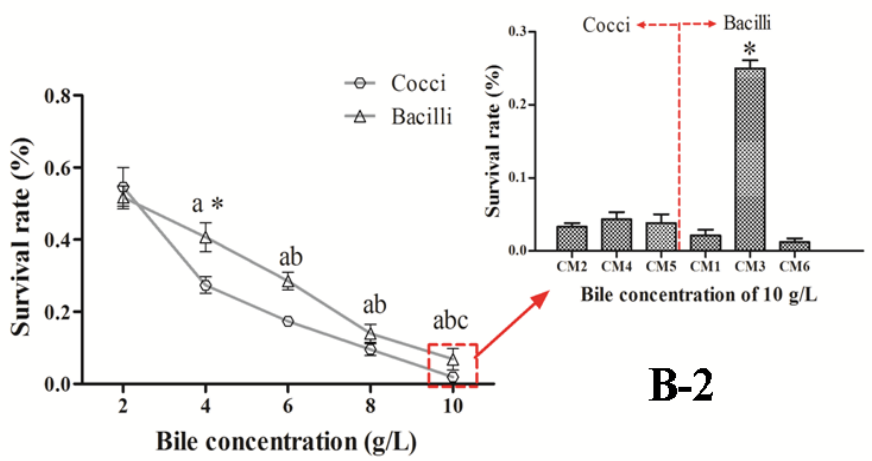

\section{B-1}

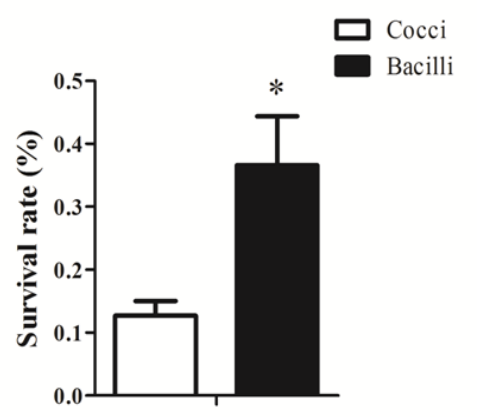

Condition of Pepsin ( $\mathrm{pH}=3.0,5 \mathrm{mg} / \mathrm{mL})$

C

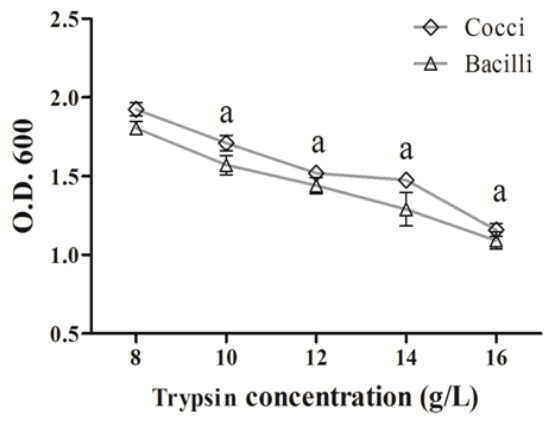

D

Figure 2. Resistance of $\mathrm{LAB}$ isolates from Muscovy duck to $\mathrm{pH}$, trypsin and antibiotics. A. LAB resistance to different levels of acidic $\mathrm{pH}$, compared with cocci, ${ }^{*} \mathrm{P}<0.05$. The survival rate of bacilli was significantly higher than that of cocci at $\mathrm{pH} 2$ and significantly increased with increasing $\mathrm{pH}$. B-1. LAB resistance to different concentration of bile; B-2. survival rate of LAB isolates in the presence of $10 \mathrm{~g} / \mathrm{L}$ bile. Both, cocci and bacilli, were resistant to bile, the different small letter superscripts mean values were comparable at $\mathrm{P}<0.05$ in the presence of $2,4,6$ and $8 \mathrm{~g} / \mathrm{L}$ bile salts, compared with cocci, $* \mathrm{P}<0.05$. C. Survival rate of LAB isolates with pepsin treatment, compared with that of cocci, $* \mathrm{P}<0.05$. D. $\mathrm{LAB}$ resistance to different concentrations of trypsin. All the data are reported as means $\pm \mathrm{SEM}$.

\section{Table 4. Antibiotic sensitivity analysis of LAB isolated.}

\begin{tabular}{lllllll}
\hline Antibiotics name & \multicolumn{5}{l}{ LAB isolates strain } \\
\cline { 2 - 7 } & $\mathrm{CM} 1$ & $\mathrm{CM} 2$ & $\mathrm{CM} 3$ & $\mathrm{CM} 4$ & $\mathrm{CM} 5$ & $\mathrm{CM} 6$ \\
\hline Ampicillin & $\mathrm{S}$ & $\mathrm{S}$ & $\mathrm{N}$ & $\mathrm{S}$ & $\mathrm{S}$ & $\mathrm{S}$ \\
Doxycycline & $\mathrm{S}$ & $\mathrm{S}$ & $\mathrm{dR}$ & $\mathrm{S}$ & $\mathrm{S}$ & $\mathrm{dR}$ \\
Erythromycin & $\mathrm{S}$ & $\mathrm{N}$ & $\mathrm{dR}$ & $\mathrm{dR}$ & $\mathrm{N}$ & $\mathrm{S}$ \\
Spectinomycin & $\mathrm{S}$ & $\mathrm{dR}$ & $\mathrm{dR}$ & $\mathrm{dR}$ & $\mathrm{dR}$ & $\mathrm{dR}$ \\
Gentamycin & $\mathrm{N}$ & $\mathrm{dR}$ & $\mathrm{dR}$ & $\mathrm{dR}$ & $\mathrm{dR}$ & $\mathrm{dR}$ \\
Ofloxacin & $\mathrm{dR}$ & $\mathrm{dR}$ & $\mathrm{dR}$ & $\mathrm{dR}$ & $\mathrm{dR}$ & $\mathrm{dR}$ \\
Macrodantin & $\mathrm{N}$ & $\mathrm{dR}$ & $\mathrm{dR}$ & $\mathrm{dR}$ & $\mathrm{dR}$ & $\mathrm{dR}$ \\
Cotrimoxazole & $\mathrm{dR}$ & $\mathrm{dR}$ & $\mathrm{dR}$ & $\mathrm{dR}$ & $\mathrm{dR}$ & $\mathrm{dR}$ \\
\hline
\end{tabular}

dR: drug-resistant; N: normal, between sensitive and resistant; S: sensitive. 


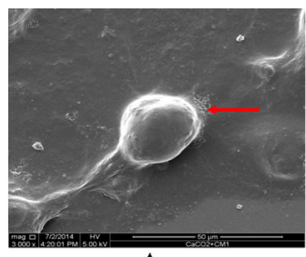

$\mathbf{A}$

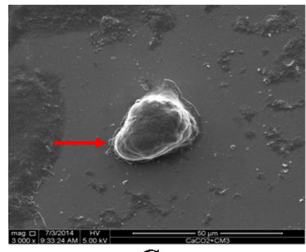

$\mathbf{C}$

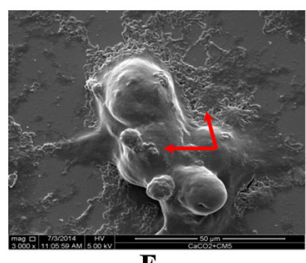

$\mathbf{E}$
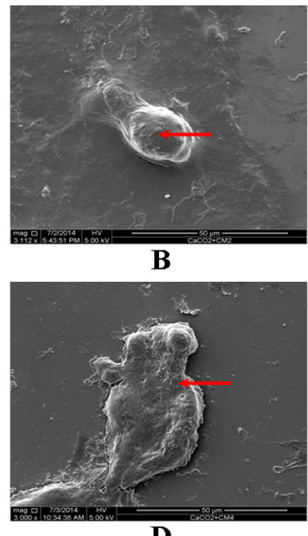

D

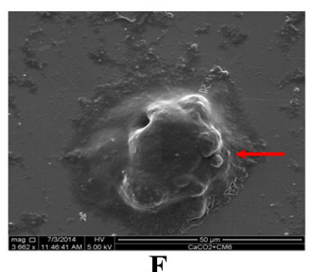

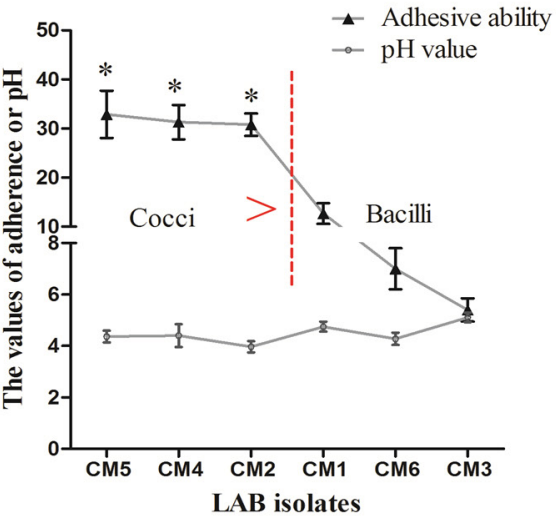

G

Figure 3. Adhesion of LAB isolates to Caco-2 cells, as determined by phase-contrast microscopy. A. CM1 isolate adhered to Caco-2 cell; B. CM2 isolate adhered to Caco-2 cell; C. CM3 isolate adhered to Caco-2 cell; D. CM4 isolate adhered to Caco-2 cell; E. CM5 isolate adhered to Caco-2 cell; F. CM6 isolate adhered to Caco-2 cell; G. bacterium cell adhesion numbers and supernatant $\mathrm{pH}$ value. Red arrows indicate bacteria. The adhesion numbers are reported as means \pm SEM. Cocci show higher adhesive ability as compared to bacilli, $* \mathrm{P}<0.05$.

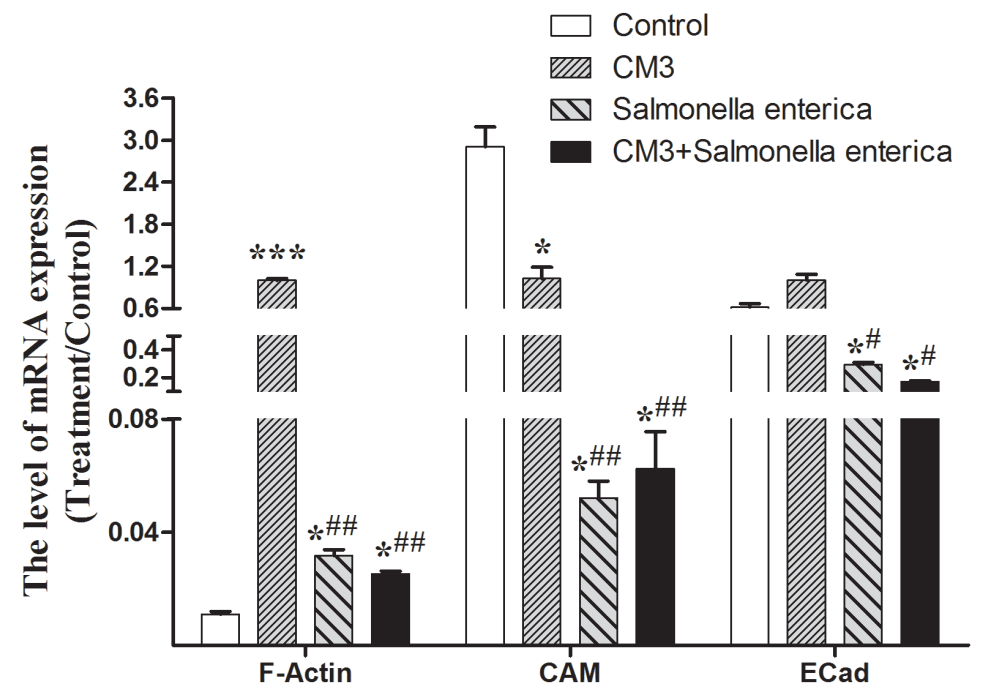

Figure 4. Expression of F-actin, CAM, and E-Cad genes in Caco-2 cells treated with CM3, Salmonella enterica or $\mathrm{CM} 3+S$. enterica. RNA extracted from Caco-2 cells was reverse-transcribed to cDNA and analyzed by real-time PCR. Compared with the control, ${ }^{*} \mathrm{P}<0.05,{ }^{* * *} \mathrm{P}<0.0001$; compared with the CM3 group, ${ }^{*} \mathrm{P}<0.05,{ }^{\#} \mathrm{P}<0.01$. 


\section{DISCUSSION}

In vivo evaluations of the health benefits of potential probiotics are time-consuming and expensive. Therefore, in vitro tests are advantageous to reduce the resources required to screen the large number of potential strains and finally identify the most effective organism (Nemcova, 1997). Relatively few in vitro studies have been conducted regarding the beneficial effect of probiotics isolated from ducks. Additionally, it is important to isolate and select probiotic strains using host-specific assays. The isolation of probiotic LABs from the same ecological niche allowed for host-specificity, especially surface properties or beneficial product, which is the first step towards identifying an ideal probiotic (Zoetendal, et al., 2006). Previous studies have shown that surface properties such as hydrophobicity, surface charge and autoaggregation, and ability to adhere to host cells are the most critical factors to combat pathogens (Ocana and Nader-Macias, 2002). As the first step for LAB colonization is adhesion to the epithelial cell surface and formation of a biofilm (Ocana and Nader-Macias, 2002), there is a significant correlation between bacterial adhesion to the host cell surface and probiotic ability (Del Re et al., 1998, 2000; Makras et al., 2006). In this study, we demonstrated these characteristics in LAB isolates from the intestinal tract of Muscovy duck, consistent with previous reports (Calderon et al., 2007; Mountzouris et al., 2007; Reddy et al., 2007; Fraga et al., 2008; Klose et al., 2010). Although only a few LAB isolates identified showed high levels of hydrophobicity and autoaggregation indices, we demonstrated that these properties are present in probiotics (Espeche et al., 2009). On the other hand, probiotic adhesion of the strains to intestinal cells also results in the release of inhibitory substances including exopolysaccharides and lactic acid (Otero et al., 2006; Martin et al., 2007; Klose et al., 2010; Karunasena et al., 2013; Kumar et al., 2013; Neissi et al., 2013; Roberts et al., 2013).

To evaluate relationship between intestinal bacteria identified in our analyses, we cultured a representative consortium of 6 enterobacteria isolates. The species-level 16S rRNA similarity to operational taxonomic units associated with Lactobacillus was confirmed by $16 \mathrm{~S}$ sequence comparison with the input and the native intestinal bacteria from our initial analyses, fulfilling Koch's postulates (Figures 1B and C). Additionally, we included LAB isolates in the consortium and showed the strongest resistance to acidic $\mathrm{pH}$ (Figure 2A). The results of this study also confirm that LAB isolates produce large quantity of lactic acid (Table 2), with bacilli showing the highest output. However, only 1 strain, morphologically identified as $L$. marinus, was shown to produce a high level of hydrogen peroxide (Table 2). In addition to hydrogen peroxide, organic acids produced by LABs also inhibit the colonization of pathogens (Rodriguez-Palacios et al., 2009). In vitro bactericidal effect was evaluated to determine the resistance to high concentrations of bile (Fernández et al., 2003; Diez-Gonzalez, 2007; Klose et al., 2010). Some secondary bile acids can impair pathogen growth in vitro, such as that produced by Clostridium difficile (Wilson, 1983; Sorg and Sonenshein, 2008). Thus, resistance to bile salts is of great importance to the survival and growth of bacteria in the intestinal tract. Of the $6 \mathrm{LAB}$ isolates, only CM3 was able to show growth in the presence of $10 \mathrm{~g} / \mathrm{L}$ bile, with a survival rate of $>25 \%$ (Figure 2B-2). This strain also showed inhibition of pathogens such as Salmonella and B. cereus (Table 3). These results are consistent with previous reports indicating that resistance to bile salts is a prerequisite for probiotics (Fernández et al., 2003).

Another important property of potential probiotics is the ability to adhere to intestinal or gastric mucin, since this is considered a pre-requisite for gut colonization and resistance against intestinal pathogens (Martin et al., 2007). In this study, 6 LAB isolates were evaluated 
for their ability to adhere to Caco-2 cells and they showed strong adhesion (Figures 3A-F). Of these, CM2, CM4, and CM5, which were morphologically identified as cocci, showed strongest adhesion (Figure 3G), attributed to a high level of surface hydrophobicity (Matisjaic et al., 2003). A previous study has implicated surface hydrophobicity as essential to attachment of bacteria to epithelial and intestinal mucosal cells (Handley et al., 1987).

Previous studies have shown that Lactobacillus can inhibit Salmonella, possibly by influencing the expression of host cell adhesion factor and subsequently, inflammation caused by Salmonella was reduced (Calderon et al., 2007). Beneficial bacteria isolated from different sources are widely used in veterinary medicine and these act mainly by producing inhibitory substances (Strompfová et al., 2006; Diez-Gonzalez, 2007; Veir et al., 2007). For example, Lactobacillus amylovorus, producing a highly acidic inhibitory substance, shows high antibacterial ability against diarrheal pathogens in pigs (Klose et al., 2010). In this study, the adhesion factor gene expression was significantly lower in the Salmonella group and CM3 + Salmonella group than in the CM3 group (Figure 4). However, CAM mRNA was higher in the CM3 + Salmonella group than in the Salmonella group. These results indicate that CM3 can be considered as a probiotic to prevent diarrheal disease. Since LABs can increase gene expression of adhesion factors, especially CAM, these can prove useful to adhere to the host cell and reduce the area available for adhesion of pathogenic bacteria. Overall, this study provides a preliminary data for the selection of probiotics to be used in animal husbandry to prevent diarrheal disease.

\section{CONCLUSIONS}

Our results indicate that surface properties such as hydrophobicity, surface charge, and autoaggregation could alter host-cell adherence and finally resistance to pathogens. This strategy could be useful to evaluate beneficial effects of microbial inoculum with probiotic properties.

\section{Conflicts of interest}

The authors declare no conflict of interest.

\section{ACKNOWLEDGMENTS}

Research supported by the Science and Technology Major Projects of Fujian Province (\#2012NZ0002), the National College Students' Innovative Project of China (\#111zc3017), and the Fujian Agriculture and Forestry University Grant (\#JCJJ13020) to D.P. Bai.

\section{REFERENCES}

Bionaz M and Loor JJ (2011). Gene networks driving bovine mammary protein synthesis during the lactation cycle. Bioinform. Biol. Insights. 5: 83-98.

Brink M, Senekal M and Dicks LM (2005). Market and product assessment of probiotic/prebiotic-containing functional foods and supplements manufactured in South Africa. S. Afr. Med. J. 95: 114-119.

Calderon O, Padilla C, Chaves C, Villalobos L, et al. (2007). Evaluation of the effect of Lactobacillus rhamnosus probiotic culture added to yogurt over Staphylococcus aureus, Escherichia coli O157:H7, Listeria monocytogenes and Salmonella enteritidis populations. Arch. Latinoam. Nutr. 57: 51-55.

Del Re B, Busetto A, Vignola G, Sgorbati B, et al. (1998). Autoaggregation and adhesion ability in a Bifidobacterium suis strain. Lett. Appl. Microbiol. 27: 307-310.

Genetics and Molecular Research 14 (4): 12262-12275 (2015)

CFUNPEC-RP www.funpecrp.com.br 
Del Re B, Sgorbati B, Miglioli M and Palenzona D (2000). Adhesion, autoaggregation and hydrophobicity of 13 strains of Bifidobacterium longum. Lett. Appl. Microbiol. 31: 438-442.

Diez-Gonzalez F (2007). Applications of bacteriocins in livestock. Curr. Issues Intest. Microbiol. 8: 15-23.

Espeche MC, Otero MC, Sesma F and Nader-Macias ME (2009). Screening of surface properties and antagonistic substances production by lactic acid bacteria isolated from the mammary gland of healthy and mastitic cows. Vet. Microbiol. 135: 346-357.

Fernández MF, Boris S and Barbes C (2003). Probiotic properties of human lactobacilli strains to be used in the gastrointestinal tract. J. Appl. Microbiol. 94: 449-455.

Fraga M, Perelmuter M, Delucchi L, Cidade E, et al. (2008). Vaginal lactic acid bacteria in the mare: evaluation of the probiotic potential of native Lactobacillus spp. and Enterococcus spp. strains. Antonie Van Leeuwenhoek 93: 71-78.

Fuller R (1989). Probiotics in man and animals. J. Appl. Bacteriol. 66: 365-378.

Handley PS, Harty DW, Wyatt JE, Brown CR et al. (1987). A comparison of the adhesion, coaggregation and cell-surface hydrophobicity properties of fibrillar and fimbriate strains of Streptococcus salivarius. J. Gen. Microbiol. 133: 3207-3217.

Karunasena E, Kurkure PC, Lackey RD, McMahon KW, et al. (2013). Effects of the probiotic Lactobacillus animalis in murine Mycobacterium avium subspecies paratuberculosis infection. BMC Microbiol. 13: 8.

Klose V, Bayer K, Bruckbeck R, Schatzmayr G, et al. (2010). In vitro antagonistic activities of animal intestinal strains against swine-associated pathogens. Vet. Microbiol. 144: 515-521.

Kumar A, Kumar M, Ghosh M and Ganguli A (2013). Modeling in vitro cholesterol reduction in relation to growth of probiotic Lactobacillus casei. Microbiol. Immunol. 57: 100-110.

Long SS and Swenson RM (1977). Development of anaerobic fecal flora in healthy newborn infants. J. Pediatr. 91: 298-301.

Makras L, Triantafyllou V, Fayol-Messaoudi D, Adriany T, et al. (2006). Kinetic analysis of the antibacterial activity of probiotic lactobacilli towards Salmonella enterica serovar Typhimurium reveals a role for lactic acid and other inhibitory compounds. Res. Microbiol. 157: 241-247.

Martin R, Heilig GH, Zoetendal EG, Smidt H, et al. (2007). Diversity of the Lactobacillus group in breast milk and vagina of healthy women and potential role in the colonization of the infant gut. J. Appl. Microbiol. 103: 2638-2644.

Matisjaic BB, Narat M and Zoric M (2003). Adhesion of two Lactobacillus gasseri probiotic strains on Caco-2 cells. Food Technol. Biotech. 41: 83-88.

Mountzouris KC, Tsirtsikos P, Kalamara E, Nitsch S, et al. (2007). Evaluation of the efficacy of a probiotic containing Lactobacillus, Bifidobacterium, Enterococcus, and Pediococcus strains in promoting broiler performance and modulating cecal microflora composition and metabolic activities. Poult. Sci. 86: 309-317.

Neal-McKinney JM, Lu X, Duong T, Larson CL, et al. (2012). Production of organic acids by probiotic lactobacilli can be used to reduce pathogen load in poultry. PLoS One 7: e43928.

Neissi A, Rafiee G, Nematollahi M and Safari O (2013). The effect of Pediococcus acidilactici bacteria used as probiotic supplement on the growth and non-specific immune responses of green terror, Aequidens rivulatus. Fish Shellish Immunol. 35: 1976-1980.

Nemcova R (1997). [Criteria for selection of lactobacilli for probiotic use]. [Article in Slovak]. Vet. Med(Praha). 42:19-27.

Ocana VS and Nader-Macias ME (2002). Vaginal lactobacilli: self- and co-aggregating ability. Br. J. Biomed. Sci. 59:183-190.

Otero MC, Ocana VS and Elena Nader-Macias M (2004). Bacterial surface characteristics applied to selection of probiotic microorganisms. Methods. Mol. Biol. 268: 435-440.

Otero MC, Morelli L and Nader-Macias ME (2006). Probiotic properties of vaginal lactic acid bacteria to prevent metritis in cattle. Lett. Appl. Microbiol. 43: 91-97.

Reddy KB, Raghavendra P, Kumar BG, Misra MC et al. (2007). Screening of probiotic properties of lactic acid bacteria isolated from Kanjika, an ayruvedic lactic acid fermented product: an in-vitro evaluation. J. Gen. Appl. Microbiol. 53: 207-213.

Roberts LM, McCahon D, Holder R, Wilson S et al. (2013). A randomised controlled trial of a probiotic 'functional food' in the management of irritable bowel syndrome. BMC Gastroenterol. 13: 45.

Rodriguez-Palacios A, Staempfli HR, Duffield T and Weese JS (2009). Isolation of bovine intestinal Lactobacillus plantarum and Pediococcus acidilactici with inhibitory activity against Escherichia coli $\mathrm{O} 157$ and F5. J. Appl. Microbiol. 106: 393-401.

Saxelin M (2008). Probiotic formulations and applications, the current probiotics market, and changes in the marketplace: a European perspective. Clin. Infect. Dis. 46: S76-S79. discussion S144-151.

Shu Q and Gill HS (2002). Immune protection mediated by the probiotic Lactobacillus rhamnosus HN001 (DR20) against Escherichia coli $\mathrm{O} 157: \mathrm{H} 7$ infection in mice. FEMS Immunol. Med. Microbiol. 34: 59-64.

Sorg JA and Sonenshein AL (2008). Bile salts and glycine as cogerminants for Clostridium difficile spores. J. Bacteriol. 190: 2505-2512.

Strompfová V, Marcináková M, Simonová M, Gancarcíková S et al. (2006). Enterococcus faecium EK13 - an enterocin a-producing strain with probiotic character and its effect in piglets. Anaerobe 12: 242-248. 
Tsirtsikos P, Fegeros K, Balaskas C, Kominakis A et al. (2012). Dietary probiotic inclusion level modulates intestinal mucin composition and mucosal morphology in broilers. Poult. Sci. 91: 1860-1868.

Tuomola EM and Salminen SJ (1998). Adhesion of some probiotic and dairy Lactobacillus strains to Caco-2 cell cultures. Int. J. Food Microbiol. 41: 45-51.

Veir JK, Knorr R, Cavadini C, Sherrill SJ, et al. (2007). Effect of supplementation with Enterococcus faecium (SF68) on immune functions in cats. Vet. Ther. 8: 229-238.

Wilson KH (1983). Efficiency of various bile salt preparations for stimulation of Clostridium difficile spore germination. J. Clin. Microbiol. 18: 1017-1019.

Xie Z, Jiang X, Ye P, Zhang Y, et al. (2015). Relationship between liver and low rumen pH in goat. Genet. Mol. Res. 14: 209221.

Zoetendal EG, Vaughan EE and de Vos WM (2006). A microbial world within us. Mol. Microbiol. 59: 1639-1650. 